\title{
THE ROLE OF THE EUROPEAN UNION IN HANDLING SYRIAN REFUGEES
}

\author{
Ria Silviana
}

Faculty of Law, University of Lampung, Indonesia, Email: riasilviana66@gmail.com

Submitted: February 6, 2019; Reviewed: February 27, 2019; Accepted: March 15, 2019

\begin{tabular}{ll}
\hline \multicolumn{1}{c}{ Article Info } & \multicolumn{1}{c}{ Abstract } \\
\hline Keywords: & The EU is a European regional organization which was \\
EU, Refugees, Syrian. & initially formed due to the economic issue. After that, \\
& the EU's focus expanded to the issue of refugees. \\
DOI: & Nowadays, the EU's problem of refugees was caused \\
10.25041/lajil.v1i1.2022 & by the phenomenon of the Arab Spring or Arab \\
& revolution that occurred in several Arab countries. \\
& Including Syria, which is part of this phenomenon. As a \\
& result of the rebellion against the Bashar al-Assad \\
& government in Syria, then causing humanitarian \\
& problems made the Syrian people feel unsafe to live in \\
& their own country, so they sought protection in various \\
& countries, including going to European countries. They \\
& thought that Europe is a safe area and looks better to \\
& provide protection for them. But not all of the EU \\
& Member States are able and willing to accept the \\
& number of refugees that arrived in their country, even \\
though the EU has the regulations regarding refugees & protection. So, the EU's role is needed to handle the \\
& Syrian refugees in its Member States. \\
\hline
\end{tabular}

\section{A. Introduction}

The Syrian warfare is because of a rebellion against the Syrian government that begins with a demonstration of the people of Syria prosecute the resignation of President Bashar al-Assad, the overthrow of his authorities and the end of five decades of Ba'ath party. The United rebels under the banner of the Syrian Liberation Military are struggling in an increasingly organized way. The Syrian conflict is an internal violent conflict in Syria. The public demonstration began on January 26, 2011, a nd developed into a national uprising. The Syrian conflict was begun from the Arab Spring ${ }^{1}$, which is 'soulless' with other revolutions in the Middle East. ${ }^{2}$ As a result of the disputes arise various problems, one of them is human rights violations. Many civilians were killed, lost their families and also lost their homes, so they had to leave the country because they felt insecure. So, they leave their country and go to other countries to get protection and asylum. They go to various countries, ranging from Arab countries to Europe.

Nine million Syrians have abandoned their homes since the begin of the conflict in March 2011. They are sheltered in neighbouring countries or in Syria. ${ }^{3}$ More than 4 million Syrian refugees are in

\footnotetext{
${ }^{1}$ Arab Spring is an Arab revolution phenomenon that occurs in several the Middle East and North African countries, where the countries are transformed from a dictatorial system into a people's sovereignty (democracy). This phenomenon began in Tunisia, Egypt, Libya, Yemen, Bahrain, and Syria.

2 Masni Handayani Kinsal, "PENYELESAIAN KONFLIK INTERNAL SURIAH MENURUT HUKUM INTERNASIONAL", Lex et Societatis. 2, no. 3, (2014): 104-112, 104.

${ }^{3}$ http://data.unhcr.org/syrianrefugees/regional.php, Accessed on November 23, 2015 at 19:00 WIB.
} 
contiguous of Syria. ${ }^{4}$ The location of Syria is close to the Arabian Gulf states, namely Saudi Arabia, the United Arab Emirates, Qatar, Oman, Bahrain, and Kuwait. However, Syrian refugees over the past few years have crossed instead into Lebanon, Jordan, and Turkey. Visa restrictions make it difficult for Syrians to entering Arabian Gulf countries and the policy for refugees stems from the complexities, and the number of the migrant is higher than the local civilians in small countries like Qatar and the United Arab Emirates. As well as Arabian Gulf states are not a party to international conventions about refugees, ${ }^{5}$ the population of the Arab countries is few, so they are unable to accommodate the number of refugees who number up to millions. ${ }^{6}$

Syrian refugees are looking for other countries that can protect them, namely European countries. There are some reasons why Syrian refugees seeking asylum in Europe, the conditions of Syrian refugees' camps in Arab countries are very concerned, drink and food supplies are insufficient. The reservation for asylum in the Arabian Gulf countries is more severe than European countries, and for them go to Europe is easier than to Arabian Gulf, because if they go to Arabian Gulf, they have to through other conflict countries (Lebanon and Iraq), if they go to Europe they just cross over the sea to arrive in destination countries. ${ }^{7}$

A total of 38 European countries noted that 264 thousand applications of asylum requests had been submitted. Compared with 2013, the increase reached 24\%. Of these, 264,000 of them are filed in 28 European Union (EU) the Member States. Germany, France, Sweden, Italy, and the UK are the top five EU countries that accept asylum applications. Antonio Guterres, Director of the United Nations High Commissioner for Refugees (UNHCR), has even asked the EU to solve the crisis of refugee. Syria became the country that requested the most for asylum in 11 of the 28 EU Member States, including 41 thousand requests submitted to Germany and 31 thousand to Sweden. Germany can accommodate up to 500 thousand refugees a year and the authorities in charge of migrants, Migrations verket, allow families of Syrian residents who have become permanent residents to move to the country. ${ }^{8}$

Based on UNHCR data on December 31, 2016, 362,753 people arrived in Europe come through the Mediterranean Sea. And last data in May 2017, 1,344 people died and disappeared, 5,765 people arrived in Greece by sea, 45,048 people arrived in Italy by sea, 2,352 people arrived in Spain by sea, and 302 people arrived in Cyprus by sea. But some European countries refuse refugees who enter their territory due to some factors, which can not bear the additional economic burden. The unemployment crisis in some countries, the burden of social security for pensioners increases, with the presence of refugees can disrupt the political and socio-cultural stability, and there as well as for racist reasons, such as the Slovaks who only accept the Christian refugees. ${ }^{9}$

Relating to the refugee issue, the EU has a regulation on asylum and refugees that is contained in the Article 78 (1) TFEU (Treaty on the Functioning of the European Union), the Treaty of Lisbon which said that the EU should expand a common policy on asylum, supplementary protection, and provisional protection to offer the appropriate status to any third-country national requiring international protection and ensuring compliance with the principle of non-refoulment. The policy that the EU makes should be in accordance with the convention and protocol on refugees, and the other treaties relating to asylum. ${ }^{10}$

The EU even has an asylum system called the Common European Asylum System (CEAS), so the Member States have an obligation to provide asylum applications for refugees who enter their territory. In addition, all of the EU Member States have ratified the Convention 1951 and the Protocol 1967. ${ }^{11} \mathrm{EU}$, as a regional organization for European countries, has the authority to solve problems in

\footnotetext{
${ }^{4}$ http://www.unhcr.org/560523f26.html, Accessed on November 23, 2015 at 19:19 WIB.

${ }^{5} \mathrm{http}: / /$ beritagar.id/artikel/berita/mengapa-pengungsi-suriah-pilih-eropa, Accessed on November 23, 2015 at 19:26 WIB.

$6 \mathrm{http}: / /$ www.cnnindonesia.com/internasional/20150908131728-134-77324/mengapa-imigran-ke-eropa-bukan-ke-timurtengah/, Accessed on November 6, 2016 at 08:28 WIB.

http://www.republika.co.id/berita/kolom/resonansi/15/09/14/nunms4319-mengapa-pengungsi-muslim-timteng-lebihmemilih-eropa, Accessed on November 6, 2016 at 08:15 WIB.

${ }^{8} \mathrm{http} / / /$ beritagar.id/artikel/berita/mengapa-pengungsi-suriah-pilih-eropa, Accessed on November 23, 2015 at 19:26 WIB.

http://www.republika.co.id/berita/kolom/resonansi/15/09/14/nunms4319-mengapa-pengungsi-muslim-timteng-lebihmemilih-eropa, Accessed on November 6, 2016 at 08:15.

${ }^{10}$ Article 78 (1) TFEU.

${ }^{11}$ www.unhcr.org/protect/PROTECTION/3b73b0d63.pdf, Accessed on May 29, 2017 at 10:31 WIB.
} 
the European region, especially the problems of its member states. Refugee problems occurring in some European countries are not only a problem for refugee recipient countries, as European countries have been integrated into a regional organization. Regionally refugee issues are also discussed on EU agendas. So much needed the role of the EU in protecting refugees coming from Syria.

Based on the description above, the issues to be discussed in this paper are as follows: first, how are refugee protection rules in international law; second, how is the EU role in handling the Syrian refugees. The research method used is normative legal research methods and the data obtained is secondary data derived from literature sources such as literature, articles, and internet sites.

\section{B. Discussion}

\section{Refugee Protection Rules in International Law}

The refugee is a status recognized by international and/or national law. A person who has been recognized his/her status as a refugee will accept the obligations and assigned rights. A refugee is at once an asylum seeker. Before a person is recognized as a refugee, he is an asylum seeker first. Instead, an asylum seeker is not necessarily a refugee. It is recognized only after its status recognized by an instrument of international law and/or national law. A person who has been recognized his/her status as a refugee will receive the rights and protection of his/her rights and the specified obligations. $^{12}$

A refugee is an individual who owing to a well-founded fear of being persecuted for reasons of race, religion, nationality, membership of a specific social organization or a political opinion, is outside his or her country, and unwilling to use the protection of that country or who no longer having a nationality and being outside the country of his former ordinary residence because of such activities, is not able or, owing to such worry, is unwilling to go back to it. ${ }^{13}$

Refugee protection rule is accommodation in the Convention on the Status of Refugees (Convention 1951) and Protocol Relating to the Status of Refugees (Protocol 1967). ${ }^{14}$ There is some protection afforded by this Convention. First, there is no discrimination. ${ }^{15}$ Second, the personal status of the refugees is regulated in accordance with the law where they are domiciled. ${ }^{16}$ Third, a refugee has the same right to have both movable and immovable property and keep it as well as others and can also transfer his assets to the country where he/she will reside. ${ }^{17}$ Fourth, States Parties to the Convention shall recognize the freedom of refugees to associate by establishing associations, including trade associations, as long as they are non-profit and non-political ${ }^{18}{ }^{1}$ Fifth, a refugee will have the freedom to go to court in front of the judiciary - sixth, entitled to get a job. ${ }^{19}$ Seventh, every refugee will be treated as same as the other citizens for the right of education. ${ }^{20}$ Eighth, every refugee will be able to enjoy the rights of social welfare. ${ }^{21}$ Ninth, every refugee is entitled to identity papers and travel documents. ${ }^{22}$ In addition to these rights, the convention also provides for refugee obligations in Article 2 which said that each refugee is obligated to comply with all of laws and regulations or provisions to create public order in the country where they live. ${ }^{23}$

Basically law is a reflection of human rights, so that law contains justice to protect a human rights. ${ }^{24}$ The refugee protection arrangements are also accommodated in the Statute of UNHCR.

\footnotetext{
12 Aryuni Yuliantiningsih, "PERLINDUNGAN PENGUNGSI DALAM PERSPEKTIF HUKUM INTERNASIONAL DAN HUKUM ISLAM", Jurnal Dinamika Hukum 13, no. 1, (2013): 159-170, 162, DOI: 10.20884/1.jdh.2013.13.1.164.

${ }^{13}$ Article 1 Refugees Convention 1951.

${ }^{14}$ Wagiman, Hukum Pengungsi Internasional (Jakarta: Sinar Grafika, 2012), 106.

${ }^{15}$ Article 3 and 4 Refugees Convention 1951.

${ }^{16}$ Article 12 Refugees Convention 1951.

17 Article 13, 14, 30 Refugees Convention 1951.

${ }^{18}$ Article 15 Refugees Convention 1951.

${ }^{19}$ Article 17, 18, 19 Refugees Convention 1951.

${ }^{20}$ Article 22 Refugees Convention 1951.

${ }^{21}$ Article 20 and 22 Refugees Convention 1951.

${ }^{22}$ Article 27 and 28 Refugees Convention 1951.

${ }^{23}$ Article 2 Refugees Convention 1951.

${ }^{24}$ Eka Intan et al., "BEGAL ANAK; PEMENUHAN HAK DAN LEMBAGA PEMBINAAN KHUSUS ANAK KELAS II A BANDAR LAMPUNG FULFILLMENT OF THE RIGHTS OF THE CHILD IN THE CLASS II SPECIAL CHILD COACHING INSTITUTION IN BANDAR LAMPUNG,” Cepalo 2, no. 2 (2018): 45-84, 76, DOI:
} 
UNHCR has procedures to provide assistance relating to the fulfilment of human rights in the form of international protection. In general, this concept includes the prevention of repatriation, assistance in the processing of asylum-seeking, legal aid and advice, promotion of physical security for refugees, promotion and voluntary redeployment, and assisting resettlement for refugees. ${ }^{25}$ Refugee Protection in the Statute of UNHCR includes the authority of UNHCR in the handling of refugees. It is contained in Article 6 of the Statute of UNHCR.

\section{The Role of the European Union in Handling Syrian Refugees}

The EU comprises 28 unique independent states with approximately 507.4 million people living within its borders. The beginning of its foundation can be traced back to the end of the Second World War when its proponents (Belgium, Germany, France, Italy, Luxembourg and the Netherlands) decided that the best way to prevent conflict was to manage coal and steel production jointly. ${ }^{26} \mathrm{At}$ first, the EU as an organization cooperated based on the three pillars of economic, political and sociolegal pillars, which were the result of the Treaty of Maastricht. ${ }^{27}$

Although the initial purpose of the European Union was economic cooperation and then developed its focus on global issues such as environmental issues, energy, asylum and so on, one of the issues that are the focus of the EU is currently the problem of asylum or refugee.

In 2014, the EU was faced the most significant number of refugees since the end of the Second World War. More than a million refugees and migrants arrive in the European Union and the majority of the refugees coming from Syria. ${ }^{28}$ Syrian refugees went to Europe using ground transportation such as buses and cars to Greece passing Turkey. After arriving in Europe/Greece, Syrian refugees went on to Sweden and Germany. ${ }^{29}$

The EU made various efforts in handling the problem of Syrian refugees which entering their territory. Syrian refugees arriving in the EU need the most basic needs, such as clean water, food, and shelter. The EU has funded humanitarian assistance projects for 50,000 refugees and migrants arrived in Greece in May 2016. The EU also provides humanitarian assistance to refugees and migrants in countries outside the EU, such as Turkey, Lebanon, Jordan, and Iraq. Turkey became the country with the largest number of refugees, about 3 million, of which 2.5 million are Syrian refugees. In order to help refugees in Turkey, the EU and its member countries provide $€ 6$ billion from 2016 to 2018. The EU has spent more than $€ 10$ billion from the EU budget to deal with the refugee crisis in 2015 and $2016 . .^{30}$

EU member countries have agreed to do relocation for 160,000 asylum seekers from Greece and Italy to the other EU countries in September 2017, according to the European Commission proposal in 2016 concerning the fairness refugees allocation in EU member states. However, in July 2016, only 3,000 asylum seekers have been relocated. The EU also wants to create safe and official ways for asylum seekers to enter the EU, so that they do not have to risk the safety of their lives, such as being smugglers and traders. ${ }^{31}$

One of how the EU is preventing more refugees from entering Europe is to enter into agreements with Turkey. In March 2016, the EU and Turkish leaders agreed on an agreement to address a large number of immigrants entering Europe. Starting on March 20, 2016, all of the new immigrants who arrive on the Greek islands, if they do not submit an asylum request or if their asylum claim is rejected, they will be returned to Turkey. Every Syrian refugee from the Greek islands is returned to Turkey, while some Syrian refugees will be relocated in the EU countries. ${ }^{32}$ Turkey will take

10.25041/cepalo.v2no2.1764.

${ }^{25}$ Wagiman, Op. Cit., 189-190.

${ }^{26} \mathrm{http} / / /$ eeas.europa.eu/archives/delegations/indonesia/documents/more_info/pub_2015_euataglance_id.pdf, Accessed on April 28, 2017 at 13:10 WIB.

${ }^{27}$ Robert Schuman, The Lisbon Treaty: 10 easy-to-read fact sheet (France: Fondation Robert Schuman, 2009$), 3$.

${ }^{28} \mathrm{http} / / /$ publications.europa.eu/webpub/com/factsheets/refugee-crisis/en, Accessed on April 9, 2017 at 14:11 WIB.

${ }^{29}$ Ani Kartika Sari. "UPAYA UNI EROPA DALAM MENANGANI PENGUNGSI DARI NEGARA-NEGARA MEDITERANIA SELATAN DI KAWASAN EROPA”. eJournal Ilmu Hubungan Internasional 3, no. 3, (2015): 548-550, 548.

${ }^{30} \mathrm{http}: / /$ publications.europa.eu/webpub/com/factsheets/refugee-crisis/en, Accessed on April 9, 2017 at 14:11 WIB.

${ }^{31} \mathrm{Ibid}$.

32 http://www.consilium.europa.eu/en/policies/migratory-pressures/countries-origin-transit/eu-turkey-statement/, Accessed on August 11, 2017 at 06:30 WIB. 
tougher measures to prevent the opening of the new sea and land routes for immigrants from Turkey to the EU. Instead, the EU will accelerate the disbursement of $€ 3$ billion allocated to address humanitarian and development needs in Turkey. The EU is also committed to providing an additional fund up to $€ 3$ billion to Turkey to help socio-economic conditions due to a large number of Syrian refugees in the country by the end of $2018 .{ }^{33}$ In addition to the above efforts, the EU is also reforming its rule on asylum. The EU rule concerning refugees is contained in Article 78 (1) of the TFEU Treaty of Lisbon. It is said that the EU must develop general policies on asylum, additional protection, and temporary protection with a meant to offer befitting status to any third-country national requiring international protection and assure compliance with the principle of nonrefoulment. This policy must be conformable with Convention 1951 and Protocol 1967 relating to the Status of Refugee, as well as all of EU Member States have ratified the convention. So, the EU Member States should fulfil the obligations that laid down by the convention.

In the effort to handle refugees, The EU and UNHCR apply the system of asylum CEAS (Common European Asylum System) implemented by EASO ${ }^{34}$ (European Asylum Support Office). The system is based on the provisions of the Convention 1951 and Protocol 1967. EU institutions such as the Council of Europe, the European Commission, the European Parliament, and the European Court have the legislative, executive and judicial powers relevant to the mandate granted by UNHCR. So, UNHCR follows EU asylum law and policy. ${ }^{35}$ CEAS began to be implemented in 1999. The EU at that time, wanted an asylum system that could address the problems in the acceptance of asylum in the European region. Therefore the EU decided to harmonize their asylum system based on binding legislation. ${ }^{36}$ It consists of several rules in CEAS, namely Asylum Procedure Directive, Reception Condition Directive, Qualification Directive, Dublin Regulation, and Eurodac Regulation. ${ }^{37}$

But, the rules was by no means designed to deal with a massive number of people arriving in a short time period. The commission is working on a suggestion to revise the existing asylum rules in accordance with current and future needs. The fundamental principle will remain equal - everyone must follow for asylum inside the first EU member states. They enter until they have got family somewhere else - however, whenever a member kingdom is overwhelmed, there need to be solidarity and honest sharing of responsibilities in the EU. ${ }^{38}$

On May 4, 2016, the European Commission presented a proposal to reform the Common European Asylum System (CEAS) by creating a fairer, more efficient and more sustainable system to allocate asylum applications among member countries. The proposal also includes changes to the Dublin Regulation/Dublin System, changes to the Eurodac Regulation/Eurodac System, and change the existing European Asylum Support Office (EASO) to the European Union Agency for Asylum. ${ }^{39}$

The Dublin System is an EU rule to determine which member states are responsible for handling any asylum applications and is not designed to determine the continuous sharing of responsibilities across the EU and ensure timely processing of the application. The proposal will make the Dublin System more transparent and improve its effectiveness while providing a mechanism for dealing with a situation of excessive pressure on member countries' asylum systems. This new system is designed to be fairer and stronger, more able to withstand refugee flows. And it will ensure the determination of the member states' responsibility to examine asylum applications and protect those in need of protection. ${ }^{40}$

\footnotetext{
${ }^{33} \mathrm{Ibid}$.

${ }^{34}$ EASO is the EU Agency established by the European Parliament and Council under the Regulation (EU) No 439/2010. This body plays a role in implementing the European Common Asylum System (CEAS). EASO was established with the aim of enhancing collaborative practice on asylum issues and helping member countries fulfill their European and international responsibility in providing protection to people in need. EASO also support the member countries whose asylum system and its acceptance is under pressure.

35 http://www.unhcr.org/publications/brochures/4e609f0d6/unhcr-european-union.html, Accessed on April 9, 2017 at 14:30 WIB.

${ }^{36}$ Federica Toscano, The Second Phase of The Common European Asylum System: A Step Forward in the Protection of Asylum Seekers? (Brussels: Institute of European Studies, 2013), 12.

$37 \mathrm{https}: / /$ ec.europa.eu/home-affairs/sites/homeaffairs/files/what-we-do/policies/european-agenda-migration/backgroundinformation/docs/20160713/factsheet_the_common_european_asylum_system_en.pdf, Accessed on April 25, 2017 at 10:54 WIB.

${ }^{38} \mathrm{http} / / /$ publications.europa.eu/webpub/com/factsheets/refugee-crisis/en, Accessed on April 9, 2017 at 14:11 WIB.

${ }^{39} \mathrm{http}: / /$ europa.eu/rapid/press-release_IP-16-1620_en.htm, Accessed on April 25, 2017 at 11:12 WIB.

${ }^{40}$ Ibid.
} 
In addition, to support the adoption of the reformed Dublin System, the commission also proposes to adapt and strengthen the Eurodac System and expand its purposes, returns facilitate and controlling the irregular migration. The proposal would extend the scope of the Eurodac Regulation that allows member states to store and retrieve data belonging to citizens of third countries or stateless persons who are not asylum seekers to get international protection and inadvertently reside in the EU, so that they can be identified for relocation and return purposes. ${ }^{41}$

One of the contents of the proposal is to change the existing European Asylum Support Office (EASO) to the European Union Agency for Asylum by adding an expanded mandate and duty to address the structural weaknesses that arise in the implementation of the EU asylum system. One of the Agency's main tasks is to operate a fair asylum mechanism under the new Dublin System. ${ }^{42}$ EASO is an EU body established by Parliament and the Council of Europe in 2010 based on Regulation (EU) no. 439/2010. ${ }^{43}$ This body was formed to protect and deal with refugee issues in the European region and to play a role in implementing CEAS. One of the refugee problems handled by EASO is the relocation for refugees. It is based on the uneven number of refugees as well as the financial problems of the recipient countries, making the reason for the relocation. This refugee relocation activity by EASO is the result of cooperation with the home country and third country to relocate refugees. This is done to refugees to get the right handling. ${ }^{44}$

The things that the EU has attempted to handle Syrian refugees conform with Article 78 of the TFEU, Treaty of Lisbon, which said that the European Union in the international safeguard policy of refugees should respect the principle of non-refoulment by not returning refugees to their home countries, and the Convention 1951 and Protocol 1967 relating to the Status of Refugees. The EU member states are the states parties of the convention shall have the responsibility to provide refugee protection as prescribed by the Convention and States Parties shall undertake a general asylum policy established by the EU.

\section{Conclusions}

The refugee protection rules in international law are stipulated in the Convention 1951 and Protocol 1967 relating to the Status of Refugee, and the Statute of UNHCR. The Convention 1951 and the Protocol 1967 contain refugee rights, refugee duties, and refoulement restrictions. States Parties to the Convention shall exercise the provisions contained in the convention. And refugee protection in the Statute of UNHCR includes the authority of UNHCR in handling refugees. The EU plays a role in handling Syrian refugees who enter their territory. Article 78 of the TFEU, Treaty of Lisbon said that the EU must provide refugee protection and in refugee, policy-making shall be in accordance with the principle of non-refoulment, Convention 1951 and Protocol 1967 relating to the Status of Refugee. The measures of the EU has taken in handling Syrian refugees are providing humanitarian aid, rescuing refugees at sea, resettlement and relocation. They make an agreement with Turkey concerning Syrian refugees and reforming EU rules on asylum/CEAS (i.e. reforming the Dublin system and the Eurodac system) and change the Asylum Support Office (EASO) to the European Union Agency for Asylum.

\footnotetext{
${ }^{41}$ Ibid.

${ }^{42}$ Ibid.

${ }^{43}$ European Asylum Support Office, European Asylum Support Office (Malta: European Asylum Support Office, 2019$), 2$. DOI: $10.2847 / 6267$

${ }^{44}$ Ani Kartika Sari. Op. Cit., 554-555. 


\section{A. Journal}

\section{References}

Kinsal, Masni Handayani. "PENYELESAIAN KONFLIK INTERNAL SURIAH MENURUT HUKUM INTERNASIONAL". Lex et Societatis 2, no. 3, 2014: 104-112.

Intan, Eka et al., "BEGAL ANAK; PEMENUHAN HAK DAN LEMBAGA PEMBINAAN KHUSUS ANAK KELAS II A BANDAR LAMPUNG FULFILLMENT OF THE RIGHTS OF THE CHILD IN THE CLASS II SPECIAL CHILD COACHING INSTITUTION IN BANDAR LAMPUNG," Cepalo 2, no. 2, 2018: 45-84, DOI: 10.25041/cepalo.v2no2.1764.

Sari, Ani Kartika. "UPAYA UNI EROPA DALAM MENANGANI PENGUNGSI DARI NEGARANEGARA MEDITERANIA SELATAN DI KAWASAN EROPA". eJournal Ilmu Hubungan Internasional 3, no. 3, 2015: 547-558.

Yuliantiningsih, Aryuni. "PERLINDUNGAN PENGUNGSI DALAM PERSPEKTIF HUKUM INTERNASIONAL DAN HUKUM ISLAM". Jurnal Dinamika Hukum 13, no. 1, 2013: 159170, 162, DOI: 10.20884/1.jdh.2013.13.1.164.

\section{B. Book}

European Asylum Support Office. European Asylum Support Office. Malta: European Asylum Support Office. 2019, DOI: 10.2847/6267.

Schuman, Robert. The Lisbon Treaty: 10 easy-to-read fact sheet. France: Fondation Robert Schuman, 2009.

Schuman, Robert. The Lisbon Treaty: 10 easy-to-read fact sheets, 2009.

Toscano, Federica. The Second Phase of The Common European Asylum System: A Step Forward in the Protection of Asylum Seekers? Brussels: Institute of European Studies, 2013.

Wagiman. Hukum Pengungsi Internasional. Jakarta: Sinar Grafika, 2012.

\section{Regulation}

Convention 1951 and Protocol 1967 Relating to the Status of Refugee. Statute of UNHCR.

Treaty on the Functioning of the European Union, Treaty of Lisbon 2007.

\section{Internet}

http://beritagar.id/artikel/berita/mengapa-pengungsi-suriah-pilih-eropa, Accessed on November 23, 2015.

http://beritagar.id/artikel/berita/mengapa-pengungsi-suriah-pilih-eropa, Accessed on November 23, 2015.

http://data.unhcr.org/syrianrefugees/regional.php accessed on November 23, 2015, at 19:00 WIB.

http://eeas.europa.eu/archives/delegations/indonesia/documen/more_info/pub_2015_euataglance_i d.pdf, Accessed on April 28, 2017.

http://europa.eu/rapid/press-release_IP-16-1620_en.htm accessed on April 25, 2017.

http://publications.europa.eu/webpub/com/factsheets/refugee-crisis/en, Accessed on April 9, 2017.

http://www.bbc.com/indonesia/dunia/2015/11/151129_dunia_turki_unieropa accessed on April 9, 2017.

http://www.cnnindonesia.com/internasional/20150908131728-134-77324/mengapa-imigran-keeropa-bukan-ke-timur-tengah/, Accessed on November 6, 2016.

http://www.consilium.europa.eu/en/policies/migratory-pressures/countries-origin-transit/eu-turkeystatement/, Accessed on August 11, 2017.

http://www.republika.co.id/berita/kolom/resonansi/15/09/14/nunms4319-mengapa-pengungsimuslim-timteng-lebih-memilih-eropa, Accessed on November 6, 2016.

http://www.unhcr.org/560523f26.html accessed on November 23, 2015.

http://www.unhcr.org/pages/4dd12ad46.html, Accessed on November 23, 2015.

https://ec.europa.eu/home-affairs/sites/homeaffairs/files/what-we-do/policies/european-agendamigration/background-information/docs/20160713/factsheet_the_common_europe an_asylum_system_en.pdf, Accessed on April 25, 2017.

www.unhcr.org/protect/PROTECTION/3b73b0d63.pdf, Accessed on May 29, 2017. 
